\title{
Związki ontologii Leibniza z wczesnymi poglądami Kanta
}

Jednym z głównych źródeł inspirujących powstanie krytycznej filozofii Kanta była doktryna Leibniza. Mówiąc o tej inspiracji, należy zwrócić uwagę na następujące momenty.

Dla Leibniza, podobnie jak dla wielu metafizyków, centralną zasadę epistemologiczną stanowiła logiczna zasada niesprzeczności. W formie algebraicznej zasada ta sprowadza się do równania pozytywnego „ $\mathrm{x}=\mathrm{x}$, lub negatywnego „ $\mathrm{x} \neq$ nie $\mathrm{x}$, co wprowadza dwa aksjomaty identyczności: pozytywny, mówiący, że przedmiot zdania poznawczego jest $\mathrm{z}$ konieczności na wszystkich etapach poznania tożsamy sam z sobą i negatywny, według którego nic nie jest tożsame ze swym przeciwieństwem. Gdy zasadę tę odniesiemy do ontologicznej kategorii substancji, otrzymamy w rezultacie logiczne zdanie "A jest B”, gdzie A (substancja) jest podmiotem, B natomiast stanowi jego predykat, przypisywany mu za pośrednictwem łącznika ,jest”. W systemie Leibniza, podobnie zresztą jak w stanowiącej dla niego ważne źródło inspiracji sylogistyce Arystotelesa, kategoria substancji spełnia funkcję podmiotu logicznego, tzn. nie jest nigdy rozpatrywana jako predykat żadnego przedmiotu poznania. Naruszenie postulatu identyczności substancji, to znaczy przypisywanie jej jako podmiotowi predykatu jednocześnie realnego i nierealnego (pozytywnego i negatywnego) powoduje sprzeczność, a w efekcie wymaga albo korekty zdania poznawczego, albo odrzucenia realności sub- 
stancji, gdyż według przyjmowanych aksjomatów, żadna rzecz nie może w pewnym określeniu jednocześnie istnieć i nie istnieć.

Przyjęcie określeń negatywnych, pociągające za sobą poważne konsekwencje metafizyczne, nie wchodzi oczywiście w doktrynie Leibniza w rachubę. Na gruncie polemiki z Kartezjuszem, postulującym nieskończoną podzielność substancji, Leibniz stawia tezę przeciwną: substancje nie są podzielne, lecz są jednościami, dlatego też definiuje on je, używając pojęcia atomu. (gr. atomon = to, co niepodzielne) lub monady (gr. monos = jednostka). Jak czytamy w „Monadologii”: „Wszystkie substancje proste, czyli monady stworzone można by nazwać entelechiami, ponieważ mają $\mathrm{w}$ sobie pewną doskonałość (échoutoi to entelés), jest w nich pewna samostarczalność (autarkeia), czyniąca z nich źródła własnych czynności wewnętrznych..."'. Natura poszczególnych substancji polega na wewnętrznej zdolności przedstawiania, a w wypadku substancji bardziej doskonałych - przedstawienia za pomocą inteligencji. Posiadają one zatem cechy psychiczne, a więc między światem monad a światem duchowym istnieje powiązanie. Dokonując kolejnego kroku, zakłada Leibniz, że substancja duchowo najdoskonalsza, obejmująca w swej inteligencji całą wielkość pozytywnej rzeczywistości, odpowiada pojęciu Boga i jest logicznie konieczna. W odniesieniu do tak rozumianej doskonałości sprzeczność jest wykluczona, jako że żaden pozytywny predykat nie może być w jej pojęciu zanegowany. W rezultacie zasada niesprzeczności logicznej stanowi u Leibniza podstawę ontologicznego dowodu na istnienie Boga. Jak wykłada filozof „nic nie może przeszkodzić możliwości tego, co nie zawiera żadnych granic, żadnego zaprzeczenia, a zatem żadnej sprzeczności, to jedno wystarcza, aby poznać istnienie Boga a priori"2.

Powyższy dowód ontologiczny stosunkowo wcześnie wzbudzał u Kanta poważne zastrzeżenia. W opublikowanej bez dwadzieścia lat przed wydaniem Krytyki czystego rozumu rozprawie Jedyna możliwa podstawa dowodu na istnienie Boga filozof, pozostając jeszcze podówczas w kręgu pytań sformułowanych przez Leibniza i, akceptując kategorię substancji koniecznej, stara się wykazać, że substancja taka ma charakter prawdy metafizycznej tylko o tyle, o ile umieszczona zostanie poza obszarem prawd logicznych. Logika nie wyznacza metafizycznego pojęcia realności, lecz odwrotnie: realność istnienia podmiotu metafizyki stanowi podstawę kompetencji prawd logicznych. Kant po raz pierwszy formułuje wówczas tezę, że przedmiotowa ważność wszel-

\footnotetext{
${ }^{1}$ G. W. Leibniz, Monadologia, przeł. H. Elzenberg, Toruń 1991, par. 18, s. 51-52.

${ }^{2}$ Tamże, par. 45, s. 57.
} 
kich pojęć, w tym pojęcia Boga, nie jest kwestią istnienia apriorycznego, gdyż obiektywny warunek prawdy wymaga także „demonstracji” tego istnienia ${ }^{3}$. Dlatego zasada niesprzeczności nie jest wystarczająca w celu przyjęcia realności logicznego podmiotu, równie dobrze bowiem, tj. bez sprzeczności poszczególnych predykatów, przyjąć można jego nieistnienie. Kant posługuje się tu następującym przykładem:

Weźcie dowolny podmiot, na przykład Juliusza Cezara. Jeśli zbierzecie w nim wszystkie dające się pomyśleć predykaty, nie wyłączając nawet tych dotyczących czasu i miejsca, to wkrótce zrozumiecie, że może on istnieć [existiren] lub nie istnieć wraz z tymi wszystkimi określeniami. Istota, która dała istnienie temu światu, a w nim i temu bohaterowi, mogłaby znać wszystkie te predykaty, nie wyłączając ani jednego, i uznawać go jednak tylko za rzecz możliwą, która nie istnieje bez jej decyzji'

Jeśli przykład ten zestawimy z leibnizowskim dowodem ontologicznym, posługującym się aksjomatem doskonałości istoty boskiej i wynikającym z niego bezpośrednio założeniem niemożliwości negacji żadnych pozytywnych orzeczeń, to jasne stają się powody, dla których interesujący nas dowód w proponowanej przez Leibniza formie jest co najmniej problematyczny. Według Kanta zdanie: „Bóg jest nieskończenie doskonały” oddaje tylko logicznie niesprzeczny stosunek między pojęciem Boga a pojęciem doskonałości. Dlatego nie mniej poprawne jest założenie, że zasada niesprzeczności pozostaje obowiązująca również wówczas, gdy pozytywny stosunek „ $\mathrm{x}=\mathrm{x}$ ” zostanie zanegowany nie tyle w części predykatu, co w jego całości. Otrzymane w takim wypadku równanie,$-\mathrm{x}=-\mathrm{x}$ ” także jest według wszelkich logicznych reguł identyczne. W konsekwencji dotychczasowa wykładnia zasady niesprzeczności wymaga zdaniem Kanta reinterpretacji. Zasada ta wyrażała tylko logiczną konieczność połączenia podmiotu i predykatu, która wobec powyższej argumentacji nie może być w sposób obiektywny identyfikowana z realną możliwością bytu obu części zdania poznawczego. Fakt ten prowadzi

3 „Tutaj szukajcie dowodu, a jeśli przypuszczacie, że go nie znajdziecie [na tej drodze], to zejdźcie z tej nieprzetartej ścieżki na szeroką drogę ludzkiego rozumu. Jest czymś ze wszech miar koniecznym, by przekonać sie o istnieniu Boga, ale nie aż tak koniecznym, aby go dowodzić". I. Kant, Jedyna możliwa podstawa dowodu na istnienie Boga, przeł. zbior., [w:] I. Kant, Dzieła zebrane, t. 1, Torun 2010, s. 613.

${ }^{4}$ I. Kant, Jedyna możliwa podstawa dowodu na istnienie Boga, przeł. Translatorium Filozofii Niemieckiej IF UMK, [w:] tenże, Dzieła zebrane, t. 1, Toruń 2010, s. 534. 
do znanej deklaracji, powtórzonej następnie, aczkolwiek na innych warunkach epistemologicznych, w Krytyce czystego rozumu: „istnienie nie jest predykatem ani określeniem jakiejś rzeczy"s.

W myśl tej deklaracji wszelkie predykaty substancji są wedle dotychczasowej funkcji zasady niesprzeczności pojęciami dotyczącymi możliwości formalnej, opartej na logicznym równaniu podmiotu i orzeczenia. W przeciwieństwie do tego Kant, usiłując nadać zasadzie niesprzeczności charakter poznania obiektywnego postuluje, by obejmowała ona także możliwość realną. Byt i myślenie nie są tym samym, a zatem błędem jest utożsamianie stosunków logicznych z realnymi. Dlatego leibnizowski dowód ontologiczny, nieuwzględniający realności istnienia logicznego podmiotu, pozostaje dla Kanta w dosłownym sensie bezprzedmiotowy. Ukonstytuowany logicznie byt może bowiem poza przedstawianiem myślącego podmiotu nigdzie nie istnieć.

Zasada niesprzeczności, pozostając podług wykładni Kanta fundamentalnym zdaniem teoriopoznawczym, określona zostaje tym samym na podstawie dwojakiego sposobu weryfikacji prawdy: formalnego, zawierającego prawa myślenia, i materialnego, dostarczającego przedmiotu myślenia.

Przedkrytyczna rozprawa Jedyna możliwa podstawa... reprezentuje w tym kontekście stanowisko stosunkowo bliskie do wypracowanego na gruncie Krytyki czystego rozumu, w którym prawdziwość lub fałszywość poznania logicznego wyznaczana jest na podstawie jego zgodności z przedmiotem. $\mathrm{Na}$ razie jednak Kant, nie dysponując jeszcze gnozeologią stworzoną w ramach filozofii krytycznej, nadal utrzymuje zasadę niesprzeczności w funkcji dowodu ontologicznego. Usprawiedliwienie takiego rozwiązania stanowi argument na to, że możliwość formalnego istnienia przedmiotu można wprawdzie w sposób logiczny obustronnie zaprzeczyć, lecz operacja taka nie da się przeprowadzić w odniesieniu do możliwości ich istnienia materialnego. Konsekwencją takiego kroku jest bowiem konieczność zaprzeczenia możliwości istnienia $\mathrm{w}$ ogóle, a to byłoby poznaniem sprzecznym $\mathrm{z}$ podstawowym doświadczeniem empirycznej realności przedmiotów. Tym samym tymczasowo uzyskuje Kant pozytywną odpowiedź na przytoczone już zasadnicze pytanie racjonalistycznej epistemologii Leibniza: „dlaczego jest raczej byt niż nic?” To, na czym zasadza się możliwość istnienia w ogóle, jest realną podstawą tego istnienia, czyli Bogiem.

${ }^{5}$ Tamże. 
Nie ulega wątpliwości, że niniejsze rozwiązanie fundamentalnego problemu Boga traktował Kant tylko jako korektę dowodu Leibniza. Filozoficzny warsztat, jakim wówczas dysponował, nie pozwalał mu na rozwiązania inne i bardziej radykalne. Istotne jest to, że w przytaczanej argumentacji zasygnalizowana zostaje obecność nowej formuły epistemologicznej, żądającej równouprawnienia faktów logicznych i empirycznych. Oczywiście formuła ta pojawia się w przedkrytycznych pismach Kanta w sposób niejasny i niedostatecznie skrystalizowany, w konsekwencji zaś dopuszcza próbę wyprowadzenia dowodu ontologicznego kategorycznie odrzuconą później na gruncie filozofii krytycznej.

Przypomniany powyżej spór o epistemologiczną wykładnię pojęcia substancji koniecznej przedstawiony został wstępnie na płaszczyźnie dowodu ontologicznego. Porównując rozwijane tu koncepcje nietrudno stwierdzić, że obaj filozofowie, zarówno Kant z okresu przedkrytycznego jak i Leibniz, zgodnie doszukiwali się w substancji wyznaczeń ontologicznych. Stanowisko Kanta jest bardziej konsekwentne. Substancja konieczna (Bóg) posiada obok istnienia logicznego także charakter podłoża realności doświadczanych empirycznie stosunków.

W powyższym kontekście nie można oczywiście pominąć faktu, że Leibniz, formułując dowód ontologiczny, zdawał sobie sprawę z epistemologicznej niewystarczalności argumentacji logiki. Antycypując poniekąd późniejsze zarzuty Kanta, przyznaje, że dowód nie stanowi wyłącznej racji, według której metafizyka powinna znaleźć podstawy konieczności bytu. Aby rację tę uzupełnić - zakłada Leibniz - wystarczy wskazać w świecie empirycznym substancję, która istnieje ponad wszelką wątpliwość, tak by postrzeżenie realności oraz analiza praw, jakim realność ta podlega, prowadziły do udowodnienia postulatu konieczności. Wyprowadzone na tej podstawie twierdzenie, znane w historii filozofii pod nazwą dowodu kosmologicznego stanowi zatem w zamyśle empiryczne dopełnienie apriorycznej tezy dowodu ontologicznego.

Z punktu widzenia źródeł kantowskiej krytyki metafizyki racjonalistycznej konfrontacja rozwiązań przedkrytycznych ze stanowiskiem przedłożonym w niniejszym „empirycznym” dowodzie Leibniza posiada niewątpliwie znaczenie decydujące. To właśnie refleksja nad realną koniecznością zjawisk składa się na genezę węzłowego aspektu późniejszej filozofii transcendentalnej, wyrażającego się w antynomii wolności i konieczności.

Rekonstrukcja dowodu kosmologicznego, opartego na drugiej centralnej w systemie Leibniza zasadzie epistemologicznej, a mianowicie na zasadzie 
racji dostatecznej, wymaga przypomnienia ważnej, postulowanej przez tego filozofa opozycji teoriopoznawczej. Według deklaracji zawartej w Monadologii system metafizyki zakłada prawdy dwojakiego rodzaju: rozumowe (aprioryczne) i faktyczne (aposterioryczne). Prawdy rozumowe są konieczne i jak wykazuje zasada niesprzeczności ich przeciwieństwo jest niemożliwe. Natomiast prawdy faktyczne są niekonieczne, a ich przeciwieństwo może zaistnieć.

Przyjmijmy na przykład, że prawdą faktycznie doświadczalną, choć niekonieczną, jest moje własne istnienie oraz fakt mojego obecnego pisania. Jedynym źródłem uzasadnienia prawdy tego faktu pozostaje, zdaniem Leibniza, wykazanie, że istnieje przyczyna sprawcza, a więc racja determinująca, pozwalająca przyjąć obok możliwości istnienia jego absolutną rzeczywistość i tą drogą także dowieść, dlaczego ja jako pewien fakt istnieję i to tak, a nie inaczej. W tym miejscu filozof trafia jednak na znaczącą trudność. Wykazanie tego rodzaju absolutnej, a mimo to realnej konieczności, jest w ramach empirycznego doświadczenia niewykonalne. Kolejne przytaczane racje determinujące będą tu zawsze tylko innymi racjami faktycznymi i niekoniecznymi, wymagającymi szeregu racji następnych, co oznacza, że analiza czynników determinujących musiałaby być serią prowadzoną w nieskończoność. W konsekwencji przyznając, że wszystkie racje faktyczne z powodu niedoskonałości ludzkiego poznania nie mogą być nam znane, wymaga Leibniz, by racja dostateczna, czyli ostatnia (Bóg), istniała poza następstwem serii. Nie jest ona niczym zdeterminowana i jako taka jest sumą wszystkich możliwych rzeczywistości, zawiera zatem także rzeczywistość najwyższą (perfectio). Określenie sposobu istnienia racji dostatecznej dokonane zostaje za pomocą przejętego od scholastyków terminu bytu eminentnego. W odróżnieniu od wywiedzionej na mocy zasady niesprzeczności rzeczywistości formalnej, w przypadku której rzecz A zawiera B tak, że w A i B jest ta sama ilość rzeczywistości, o rzeczywistości eminentnej wnioskujemy wówczas, gdy A zawiera B, posiadając więcej rzeczywistości. Ostatnia racja rzeczy istnieje właśnie w sposób eminentny, tzn. zawiera w sobie jako ostateczna potencja każdą możliwość poszczególnych prawd empirycznych.

Zasadność powyższego wywodu kwestionuje Kant już w opublikowanej w roku 1755 rozprawie habilitacyjnej Nowe wyjaśnienie pierwszych zasad poznania metafizycznego. Królewiecki filozof oświadcza, że zakładając rzeczywistość racji dostatecznej, a tym bardziej podając rację tę $\mathrm{w}$ formie dowodu aposteriorycznego, czyli wynikającego z doświadczenia, choćby tylko ograniczonego do doświadczenia własnego istnienia, nie dokonuje się mimo 
to przejścia od logicznego dowodu a priori do dowodu empirycznego. Z niniejszej tezy wynika przedstawiona w Nowych wyjaśnieniach... kolejna modyfikacja teorii Leibniza dotycząca zasady racji. Pojęcie racji interpretuje Kant dwojako: oznaczać ono może albo rację poprzedzającą jako podstawę powstania rzeczy, albo następującą, na mocy której uzyskujemy podstawę poznania rzeczy ${ }^{6}$. Racja następująca, analogicznie jak zasada niesprzeczności, jest racją zadowalającą, ponieważ konstatując empiryczny fakt istnienia rzeczy z całą pewnością stwierdzamy, że taka rzecz istnieje i że może być dalej określana. Chcąc jednak odpowiedzieć na postawione przez Leibniza pytanie, dlaczego rzecz musi istnieć z koniecznością, tzn. tak, a nie inaczej, należałoby wskazać rację poprzedzającą, będącą podstawą bytu lub stawania się rzeczy. Jakkolwiek w świecie zjawisk empirycznych racje takie niewątpliwie istnieją i mogą być faktycznym przedmiotem poznania, to w odniesieniu do substancji koniecznej, wymagającej określenia jako racja absolutna, poznanie to wydaje się co najmniej wątpliwe.

Oczywisty jest fakt, że pojęcie racji dostatecznej, mimo przyjęcia przesłanek empirycznych, pozostaje pojęciem czysto rozumowym (tym, co później Kant nazwie ideą regulatywną). Niemożliwość odtworzenia pełnego szeregu wszystkich kolejnych racji stwarza swoistą lukę poznawczą, w obliczu której empiryczny przypadek mego istnienia wcale nie musi implikować twierdzenia, że posiada ono rację konieczną, a tym bardziej, że jest nią Stwórca. Wnioski rozumowe starają się wprawdzie lukę tę zapełnić, jednak dzieje się to za cenę oderwania ciągu argumentacji od obranego punktu wyjścia. Dowód Leibniza nie wychodzi zatem poza relacje wnioskowania apriorycznego, opartego w tym kontekście na logicznie umotywowanym związku przyczynowo-skutkowym. Zakładane pryncypium empirycznej prawdy jako rzeczywistej przesłanki twierdzenia teologicznego jest więc zakładaniem pryncypium mylnego.

Wykraczając poniekąd poza wnioski sformułowane przez Kanta, warto zauważyć, że przyjęte w wykładni zasady racji pojęcie bytu eminentnego nie da się w oczywisty sposób przystosować do zasady niesprzeczności, postulującej identyczność określonego podmiotu z samym sobą. Aby pogodzić zasadę niesprzeczności z zasadą racji dostatecznej, pojęcie racji musiałoby być analityczne, czyli zawarte podług równania „ $\mathrm{x}=\mathrm{x}$ " $\mathrm{w}$ pojęciu podmio-

${ }^{6}$ I. Kant, Nowe wyjaśnienie pierwszych zasad poznania metafizycznego, przeł. A. Grzeliński, [w:] I. Kant, Działa zebrane, t. 1, Toruń 2010, s. 392; por. M. Żelazny, Idea wolności w filozofii Kanta, Toruń 2010, s. 27. 
tu, nie przedstawiając żadnych wyznaczeń zewnętrznych. Fakt ten stanowi też fundament wywodu Leibniza: dowieść jakiejś prawdy oznacza tyle, ile sprowadzić ją do prawdy z nią identycznej, czyli zdać z niej sprawę (reddere rationem). Dla Leibniza są to terminy synonimiczne, stąd nazwa zasady racji ${ }^{7}$. Podstawowym aksjomatem zasady racji jest właśnie ten, że „nie ma wyznaczeń czysto zewnętrznych" ${ }^{\prime}$. Stosowne racje także i tu muszą więc tkwić w podmiotach jako identyczne z predykatami. Opierając się na poczynionej przez Kanta modyfikacji, aksjomat ten rzeczywiście możemy przyjąć, gdy rozpatrujemy w sposób analityczny kolejne racje faktyczne, a pominiemy niekonsekwentnie wprowadzone przez Leibniza pojęcie pozaświatowego Boga. Racja przedmiotu, jako jego przyczyna, może bowiem w stosunkach logicznych odpowiadać jednej z właściwości owego przedmiotu. Chcąc jednak analitycznie interpretować pojęcie racji ostatniej, należałoby wykładać metafizykę Leibniza jako panteizm, co jednak wyraźnie kłóciłoby się z deklaracjami samego filozofa, definiującego pojęcie Boga jako intelligibilia extramundane lub supramundane, przypisującego mu zatem jednoznacznie istnienie pozaświatowe. Aksjomat identyczności zostaje w tym przypadku przez Leibniza pominięty. Pozostaje pytanie, czy filozof niekonsekwencji tej nie dostrzegał, czy też nie potrafiąc jej w ramach przyjętej metody rozwiązać, dostrzec nie chciał.

Jak wynika z powyższych spostrzeżeń, proponowana przez Kanta modyfikacja posługiwania się zasadą racji wyklucza jej przydatność jako empirycznej podbudowy teologii. $\mathrm{W}$ okresie przedkrytycznym prawdziwym zadaniem metafizyki pozostawał dowód ontologiczny wyprowadzony z zasady niesprzeczności. Ale w takim wypadku logika zmusza tu do jednoznacznej deklaracji: transcendentny byt albo jest, albo go nie ma; trzecia możliwość (wyłączony środek) nie istnieje. Zarówno Leibniz jak i Kant wybierają oczywiście „jest” i wobec ograniczeń spowodowanych postulatem jedności prawdy trudno byłoby oczekiwać innego rozwiązania. Ale łatwo zauważyć, że Kantowska interpretacja zasady niesprzeczności, podług której substancja konieczna jest podstawą możliwości istnienia świata empirycznego, stwarza w świetle zasady racji pewien specyficzny wyjątek. Krytykując Leibniza, Kant odrzucał realność poznania transcendentnej podstawy rzeczywistości i przyczynową zasadę racji przedstawiał jako bezwarunkowo obowiązującą tylko w odniesieniu do składających się na immanentny świat przyrody zjawisk

${ }^{7}$ G. W. Leibniz, Monadologia, s. 15.

${ }^{8}$ Tamże, s. 16. 
empirycznych. Dlatego, nie chcąc wykładać istnienia świata jako „bezpodstawne" i naruszać tym samym jedności prawdy poznania, nie mógł mieć innej alternatywy jak zgodzić się na „wyjątek” dla dowodu ontologicznego. Jednocześnie zdawał sobie jednak sprawę, że rozwiązanie to nie usuwa w istocie podstawowych wątpliwości. Dowód na istnienie Boga, nadający Bogu status przypadku nadzwyczajnego, łamiącego prawo przyjętej w zasadzie racji formuły epistemologicznej, był rozstrzygnięciem zaledwie połowicznym.

Wątpliwości teologiczne pogłębiał niewątpliwie inny i nie mniej ważny w filozofii przedkrytycznej wątek zainteresowań Kanta dotyczący zagadnień etycznych. Gdy bowiem także na gruncie etyki ograniczymy pole zastosowania zasady racji do przedmiotów, których istnienie da się wykazać tylko w przyrodzie, musimy zgodzić się z tezą, że wspólnym podłożem wszystkich obserwowanych zjawisk jest fakt bycia zdeterminowanym. W tym sensie zjawiska świata moralności, obejmujące potencjalne działania człowieka wobec bliźnich także powinny posiadać podstawę empiryczną, tłumaczącą fenomen działania poprzez wskazanie na należący do przyrody warunek poprzedzający. Koncepcja ta, rozpatrująca moralność w kategoriach czysto mechanistycznych, jest oczywiście trudna do przyjęcia. Negowałaby ona możliwość podmiotowego podejmowania autonomicznych decyzji moralnych i w ogóle wykluczałaby zasadność pytania o wolność.

To właśnie w tym kontekście krytyka zasady racji prowadzi do postawienia problemu wolności. Celem metafizycznej refleksji Kanta jest zgodnie $\mathrm{z}$ oświadczeniem zawartym w przedmowie do Krytyki czystego rozumu wykazanie, że idea wolności nie jest „sama w sobie sprzeczna”. Postulat ten, realizowany $\mathrm{w}$ świetle teorii Leibniza, stawia jednak pod znakiem zapytania możliwość metafizyki jako nauki będącej logiką absolutnej rzeczywistości. Jeśli bowiem odwołamy się tu do propozycji Leibniza, to okazuje się, że nie potrafił on rozwiązać zagadnienia wolności w sposób pozbawiony paradoksów i niekonsekwencji. Co więcej, wskutek interpretacji przedstawionych przez niego dowodów doktryna pozaświatowego i niematerialnego Boga nie da się utrzymać. Tym samym - $\mathrm{w}$ aspekcie ontologicznym - powoduje to upadek kategorii substancji doskonałej jako naczelnego pojęcia metafizyki. Fakt ten wynika $\mathrm{z}$ następującej argumentacji.

Pozostający w ramach chrześcijańskiej wizji świata system Leibniza wyrósł niewątpliwie z potrzeby logicznej akceptacji prawd zawartych $\mathrm{w}$ objawieniu biblijnym. Podejmując się tego zadania, nie mógł filozof pominąć prawd dla

\footnotetext{
${ }^{9}$ Krytyka czystego rozumu, przeł. R. Ingarden, t. 1, Warszawa 1957, s. 42.
} 
człowieka ostatecznych, bo dotyczących samookreślenia ze względu na zakomunikowaną w tym objawieniu nadzieję na ponadczasowy wymiar istnienia. Realizacja owej nadziei możliwa jest, jak głosi tradycja biblijna, przy założeniu, że człowiek posiada wolną wolę, podług której kieruje się w swym postępowaniu pragnieniem dobra. Jednak koncepcja Leibniza analogicznie jak w przypadku aktów poznawczych podporządkowuje działania woli percepcjom intelektualnym, przyjmując na gruncie moralności, że te ostatnie, jako niedoskonałe, apriorycznie ograniczają możliwość całkowitej realizacji dobra. W rezultacie rzeczywistość logiki postawiona zostaje ponad rzeczywistością moralną.

Punkt wyjścia leibnizowskiej teorii wolności tworzą dwa poniższe twierdzenia:

W dobrowolnych czynach nie ma przymusu, bo jeśli nawet w naszym umyśle największe znaczenie miałyby przedstawienia rzeczy zewnętrznych, jednak nasze dobrowolne działanie zawsze jest samorzutne, to znaczy jego zasada jest w działającym. Zawdzięczamy to zawczasu ustanowionej na początku przez Boga oraz dającej się wytłumaczyć [...] harmonii między ciałem a dusząa ${ }^{10}$.

Także przewidywanie i ustanowienie zawczasu ładu przez Boga nie wprowadzają konieczności, chociaż same są niepodważalne. Bóg bowiem ujrzał te rzeczy, które mają nastąpić, w idealnym łańcuchu możliwości, wśród nich zaś dobrowolnie grzeszącego człowieka, a po to, by ów łańcuch zaczął istnieć, Bóg nie zmienia natury rzeczy i nie czyni koniecznym tego, co było przypadkowe ${ }^{11}$.

Twierdzenia te wymagają oczywiście szerszego komentarza. Podstawową w ontologii Leibniza kategorię substancji rozdziela filozof na tę posiadającą aspekt cielesny, który składa się na świat dany w percepcji zmysłowej (mundus sensibilis) i tę, przejawiającą aspekt duchowy, na mocy którego świat jest intelektualnie percypowany (mundus intelligibilis). Harmonia między ciałem a duszą polega na założeniu, że percepcja świata jest działaniem czysto wewnętrznym. Każda z substancji wyraża wszystkie pozostałe w akcie percepcji, stając się w ten sposób „Zwierciadłem wszechświata”. Postrzeżenia są więc indywidualnymi modyfikacjami stanów wewnętrznych i o tyle, o ile są doskonałe, świat ten jest poznawany jako idealna harmonia. Substancja konieczna (Bóg) potrafiąca, jako umysł nieskończony, przedstawiać świat jako

${ }^{10}$ G. W. Leibniz, Pisma, s. 115-116.

11 Tamże, s. 114. 
stale uobecnianą jedność, jest najdoskonalsza dlatego, że będąc czystym intelektem, wolna jest ona od percepcji zmysłowej, wprowadzającej niepożądany dysonans w intelektualnej harmonii. Zasadniczym powodem niedoskonałości ludzkiego obrazu świata jest zatem jego ograniczenie przez zmysłowość.

Podobną drogę rozumowania obiera Leibniz również w dziedzinie pytań moralnych. Niedoskonałość jest ograniczeniem percepcji, zło wynika z braku dobra. Aksjologicznie doskonałe dobro, jako oczywisty składnik doskonałości, istnieje wyłącznie w intelekcie nieograniczonym, dlatego istota obrazująca dobro w sposób maksymalny i dążąca poprzez działanie do jego urzeczywistnienia jest absolutnie wolna. Stworzenie świata, czyli akt wolnej woli tej istoty, tłumaczy filozof zamiarem urzeczywistnienia chcianego dobra, co sprawia, że - jak stwierdza - żyjemy w najlepszym z możliwych światów. Teodycea Leibniza, próbując usprawiedliwić Boga w obliczu istniejącego w tym świecie zła, uzasadnia je niedoskonałością ludzkiej percepcji, która jako skończona nie posiada danej Stwórcy możliwości jasnego i wyraźnego przedstawienia dobra. Etyka Leibniza jest więc etyką intelektualnej percepcji, co w rezultacie implikuje postawienie rzeczywistości logiki ponad rzeczywistością moralności. Mimo tego filozof próbuje dowieść, że z powodu przydanej niedoskonałości poznania człowiek nie jest zmuszony w sposób "przedustawny" postępować źle, gdyż dysponując zdolnością intelektualnego doskonalenia własnych percepcji może zła unikać i powinien jako istota rozumna dążyć do tego, co najlepsze. W wymiarze eschatologicznym wniosek ten stanowi w rozumieniu Leibniza objaśnienie biblijnej wizji kary i nagrody.

Powyższa koncepcja, uzależniająca stopień wolności od intelektualnej doskonałości poznania, zmusza jednak do postawienia pytań, których Leibniz nigdy nie poruszył. Nie stawia ich także Kant, choć powody braku tych pytań są w obu systemach krańcowo różne. W ramach doktryny Leibniza wykraczałyby one bowiem poza logiczną hermeneutykę Biblii, dla Kanta natomiast dotykałyby tajemnicy, której rozwikłanie leży poza możliwościami poznania konstytutywnego, i które w efekcie nie mogą się stać przedmiotem filozofii.

Przypisując mianowicie Bogu percepcję intelektualnie absolutną, potrafiącą ująć dobro w całej jego doskonałości, należy także przyjąć, że przejawiający w tej percepcji świat doskonałości tej odpowiada i to w najdrobniejszych szczegółach. Aksjomatem jest tu konieczność wywiedziona na mocy logicznej zasady niesprzeczności, przyjmowanej w teorii Leibniza jako fundamentalne kryterium poznania intelektualnego właściwej więc także dla intelektu absolutnego. Świat powinien zatem być albo dobry tylko a priori, albo jego pojęcie jest sprzeczne. Skoro jednak nie istnieje on jako niesprzeczna prawda 
konieczna, lecz jest światem prawdy faktycznej zawierającym empiryczne zło, musi być światem niekoniecznym. W rezultacie powstaje pytanie o rację jego istnienia, czyli dlaczego Bóg w ogóle stworzył świat? Leibniz odpowiedziałby, że istotą każdej monady jest działanie polegające na wewnętrznym przedstawianiu. Bóg zatem, będący monadą najdoskonalszą, nie mógł nie działać świat jest aktem jego myślenia. Ale myślenie takie byłoby niekonsekwentne: aprioryczna doskonałość nie pokrywa się w intelekcie Boskim z faktycznym brakiem doskonałości. Jedyną możliwością pogodzenia doskonałości z racją istnienia niedoskonałości, a w języku logiki zasady niesprzeczności z zasadą racji jest hipoteza, że rację niedoskonałości stanowi osiąganie coraz większej doskonałości.

Innymi słowy Bóg był zdeterminowany do stworzenia świata takiego, jaki jest, gdyż nawet jeśli posiadał przedstawienie dobra, to nie mógł zrealizować go bez pośrednictwa natury. W tym zaś sensie absolutna wolność pozaświatowego i bezcielesnego Boga jest sprzeczną w sobie fikcją, a stanowisko Leibniza - niedającym się uniknąć błędem metafizycznym.

Kant z pewnością dostrzegał paradoksy, z jakimi mamy do czynienia w leibnizowskiej koncepcji wolności. Świadomy był faktu, że próba pogodzenia ezoterycznego języka Biblii z kategoriami logiki nie może warunkować niesprzeczności zasad moralnych, przede wszystkim ze względu na dwa postulaty: teologiczny i antropologiczny. Wynikająca z koncepcji Leibniza realizacja coraz większej doskonałości świata zakłada z koniecznością warunek czasu, a tu trudno przyjmować obok czasu empirycznego jakiś czas ponadempiryczny, w którym Bóg urzeczywistniałby dobro, gdyż tak czy inaczej byłby wówczas istotą immanentnie przez czas zdeterminowaną. Dlatego także w aspekcie moralno-teologicznym, widząc potrzebę skorygowania błędu Leibniza, rezygnuje Kant ze spekulacji wywodzących doskonałość Boga. Jest zdania, że język biblijnego mitu nie może być zredukowany do żadnych logicznych odpowiedników. Podobne wnioski dotyczą aspektu antropologicznego. Pozostając na gruncie antropologii badającej człowieka jako istniejący w świecie fakt empiryczny, ideę wolności możemy uznać - jak czynił to Leibniz - tylko za przedstawienie ciemne. Istniejące w czasie substancje zewnętrzne uzależniają podstawę działania od wrażeń zmysłowych.

Jak wynika z powyższych spostrzeżeń leibnizowska teodycea prowadzi do niebezpiecznych dla metafizyki spekulacji, których rezultatem jest negacja samoistności Boskiej woli. Prawa intelektu ludzkiego, konstruujące wiedzę na zasadzie dychotomii obu rodzajów prawd - apriorycznych i empirycznych rzutowane są według projektu „unii logicznej” na intelekt boski, zmuszając 
go jednocześnie do przezwyciężenia owej dychotomii poprzez uwikłanie w świat materialny. Z kolei, gdyby przyjąć tezy Leibniza, z punktu widzenia moralności człowieka nie da się utrzymać wolności. Przeciwnie, brak czystości poznania intelektualnego uniemożliwia działanie kierujące się dobrem, skazując nas mimo wszelkich wysiłków na czynienie zła.

Dlatego głównym zamierzeniem Kantowskiej filozofii moralności jest całkowite uwolnienie pytania o wolność od twierdzeń zakładających sprzeczność i to według obu powyższych postulatów. Jak proponuje Kant sprzeczności pierwszej, wynikającej $\mathrm{z}$ niemożliwości pogodzenia jednoczesnego funkcjonowania $\mathrm{w}$ intelekcie boskim obu zasad logicznych - apriorycznej i empirycznej - unikamy wówczas, gdy nie przypisujemy Bogu obowiązku stworzenia empirycznego świata zmysłów.

Świat zmysłowy to przecież zespół faktów istniejących w czasie i przestrzeni, a więc tylko przyroda, Bóg zatem, tworząc ten świat, nawet jeśli pojmować go jako twórcę wszelkich czasów, musiałby być ich początkowym punktem, przyczynowość praistoty ${ }^{12}$. W przeciwieństwie do tego, gdy założymy, że Bóg nie jest twórcą empirycznych określeń czasowych, istniejące w czasie zło nie musi być z koniecznością uzasadniane, tak jak w cytowanym fragmencie Leibniza, Boskim planem stworzenia.

Sprzeczność druga natomiast przestaje istnieć, gdy doskonałość ludzkiej percepcji dobra nie zakłada warunku antropologicznego, czyli percepcji substancji $\mathrm{w}$ czasie $^{13}$. Tu zawsze powstaje przyczynowo-skutkowa antynomia pomiędzy wolnością i koniecznością, której nie da się, jak chciał tego Leibniz, usunąć na drodze poznania spekulatywnego.

Dla Kanta moralność nie jest dziedziną filozofii spekulatywnej, lecz stanowi akt praktycznego działania będącego w mocy urzeczywistniać dobro bez względu na warunki zmysłowe, zatem wymaga ona innych niż spekulatywne zasad poznawczych. Stąd wypływa fundamentalny w filozofii Kanta podział przedmiotów metafizyki:

Metafizyka - definiuje Kant - dzieli się na metafizykę spekulatywnego zastosowania czystego rozumu i na metafizykę jego zastosowania praktycznego, i jest przeto albo metafizyką przyrody, albo metafizyką moralności. Tamta zawiera wszystkie czyste [uzyskane] z samych pojęć [...] principia rozumowe po-

\footnotetext{
${ }^{12}$ I. Kant, Krytyka praktycznego rozumu, przeł. I. Gałecki, Warszawa 1983, s. 166.

${ }^{13}$ I. Kant, Krytyka czystego rozumu, t. 2, s. 586.
} 
znania teoretycznego wszelkich rzeczy, ta zaś principia, które określają a priori działanie i poniechanie [czegoś] i czynią je koniecznym ${ }^{14}$.

Zasygnalizowane powyżej wątki kantowskiej filozofii wolności są oczywiście owocem przemyśleń prezentowanych w pracach krytycznych. Na razie jednak, szczególnie w rozprawie habilitacyjnej, nie widzi Kant innego rozwiązania, jak zadeklarowanie kolejnego obok dowodu na istnienie Boga wyjątku, na mocy którego podmiot moralny zostaje wyłączony spod prawa zasady racji determinującej. Kant powołuje się tu na dokonane przez Leibniza rozróżnienie przyczynowości zewnętrznej, przysługującej substancjom jako ciałom przedstawianym w percepcji zmysłowej, od ich przyczynowości wewnętrznej, sprowadzającej się do samej możliwości przedstawiania. Jak wiemy, Leibniz definiował substancje jako jedności samowystarczalne, będące „źródłem swoich wewnętrznych czynności". Przypisywał im zatem charakter ciał dynamicznych. Właśnie w dynamistycznym rozumieniu substancji dopatruje się Kant szansy wykazania determinizmu wewnętrznego, mogącego stanowić podstawę kategorii wolności. Ale w opozycji do Leibniza nie sugeruje on, by warunki urzeczywistnienia wolności ograniczone były mechanizmami zewnętrznymi, powodującymi „niewyraźność" intelektualnego przedstawienia dobra. Już wówczas zdawał sobie sprawę, że rozpatrywanie uczynków moralnych z pozycji antynomii świata zmysłowego i intelektualnego jest na gruncie etyki co najwyżej jałową spekulacją, nierozwiązującą żadnych podstawowych wątpliwości. Dlatego na kartach rozprawy habilitacyjnej zaprezentowana została teza, wedle której podmiot, niezależnie od percepcji zmysłowych, dysponuje w ramach determinacji wewnętrznej możliwością przedstawienia czystego dobra. Decyzja, czy realizujący to przedstawienie uczynek zostanie dokonany, zależałaby w takim przypadku od autonomicznej woli podmiotu i w tym sensie byłaby wyborem całkowicie wolnym. Pamiętając jednak o bezwarunkowym prymacie zasady racji, Kant dostrzega oczywiście fakt, że tak pomyślana autonomia woli nie może istnieć bez względu na określenia czasowe, stanowiące konieczne determinacje zewnętrzne. Porządek świata przyrody pozostaje prawem nadrzędnym i możliwość wewnętrznego przedstawiania nie ma tu żadnej siły ingerującej. W tym kontekście działanie wolne jest o tyle wyjątkiem, o ile zapoczątkowane zostaje $\mathrm{w}$ razie niezaistnienia przyczyn zewnętrznych. Reasumując: przedkrytyczna teoria wolności uwarunkowana jest dwojako. Wymaga podstawy negatywnej, zakładającej nie-

${ }^{14}$ Tamże. 
istnienie determinacji zewnętrznej i pozytywnej, polegającej na determinacji wewnętrznej, wynikającej z przedstawienia dobra ${ }^{15}$.

W porównaniu z poglądami Leibniza propozycja ta wydaje się bardziej wiarygodna. Wyraźnie dochodzi tu do głosu projekt wyłączenia pobudek moralnych spod praw czasowego ciągu przyczynowo-skutkowego, rozwinięty później w Krytyce czystego rozumu poprzez rozróżnienie idei matematycznych i dynamicznych. Jednak na gruncie przedkrytycznych koncepcji gnozeologicznych projekt ten nie mógł zostać w pełni zrealizowany. Przede wszystkim dlatego, że Kant nie brał wówczas pod uwagę potrzeby oddzielenia obu warunków wolności (podstawy negatywnej i pozytywnej) od ontologicznego fundamentu świata. W ostatecznym rezultacie Bóg, będący według litery dowodu ontologicznego warunkiem możliwości istnienia w ogóle, warunkowałby pośrednio także obie podstawy wolności, stwarzając w przyrodzie korzystny lub niekorzystny dla jej realizacji porządek faktów. W tym sensie decyzji moralnych, analogicznie jak w systemie Leibniza, nie można tu oceniać jako w całości leżących w kompetencjach przyczynowości działających w świecie substancji, lecz nadal pozostają one wpisane w skonstruowany przez Boga mechanizm świata.

Nieudana próba rozwinięcia zmodyfikowanej koncepcji etycznej - bo tak trzeba by interpretować propozycję zaprezentowaną przez Kanta w pracy habilitacyjnej - nie rozstrzyga także problemu, który dla Leibniza był zasadniczym motywem zmuszającym do zabrania głosu w kwestiach moralnych. Zamierzeniem leibnizowskiej teorii percepcji dobra było, jak wiemy, uzasadnienie, że człowiek, jako monada będąca przede wszystkim zespołem cech duchowych może jeśli nie decydować, to przynajmniej współdecydować o pośmiertnych losach własnego istnienia. Fakt niezniszczalności duszy jest dla Leibniza oczywisty, wynika bowiem w prostej linii z założenia niepodzielności substancji. Już w pierwszych paragrafach Monadologii filozof wdaje się w spekulacje mające dowieść, że substancje proste, którym przypisuje status jedności pierwotnych, nie ulegają w sposób naturalny rozkładowi i dlatego muszą istnieć w sposób ciągły. Tylko ingerencja potęgi Boskiej mogłaby „za jednym zamachem" istnienie to powołać lub unicestwić ${ }^{16}$.

W tym kontekście również w refleksji Kanta musiało pojawić się pytanie o nadrzędny cel wewnętrznej determinacji skłaniającej do wyboru postępowania zgodnego z postulatami moralności. Mimo że zasięg usiłowań czło-

\footnotetext{
${ }^{15}$ Por. M. Żelazny, Idea wolności w filozofii Kanta, Toruń 2001, s. 26 i nast.

${ }^{16}$ G. W. Leibniz, Monadologia, pkt. 6, s. 47.
} 
wieka pragnącego maksymalnej realizacji dobra może być nikły, to przecież daje się on na zasadzie wyjątku przyjąć bez naruszania zasady racji. Jednostka wykorzystująca zaistnienie w przyrodzie warunków do działania podług pryncypiów dobra powinna zatem oczekiwać motywacji uzasadniającej, dlaczego ma wyrzekać się zła, czyli także ewentualnych doczesnych korzyści, jakie mogłyby dla niej płynąć z tytułu „posłuszeństwa” wobec zewnętrznej determinacji przyrody. Motywacja taka, co oczywiste, nie może wynikać z zasad empirycznych, gdyż należałaby wówczas do dziedziny materialnych, przyczynowo-skutkowych praw przyrodoznawstwa i ustawałaby wraz z istnieniem materialnym. Kant zdawał sobie zatem sprawę, że w jego koncepcji brakuje wyraźnego stanowiska eschatologicznego, za pomocą którego mógłby, podobnie jak Leibniz, przedstawić argumenty przemawiające za opłacalnością dobra. Jednak stanowisko takie wymagałoby próby przełożenia prawdy biblijnej na filozoficzną, czyli zadeklarowania trzeciego z kolei wyjątku od zasady racji, postulującego ponadempiryczne trwanie skutków determinacji wewnętrznych i ich ocenę $\mathrm{w}$ rozumie boskim.

Tu jednak królewiecki filozof zauważał trudności, które w aspekcie poczynionych uprzednio modyfikacji systemu Leibniza wydawały się nieusuwalne. Przyjęcie ponadempirycznego trwania podmiotu moralnego, sprowadzające się w istocie do wykazania nieśmiertelności duszy, nie da się pogodzić z wypracowanymi wcześniej zasadami teorii poznania, tzn. dowieść, przy spełnieniu kryteriów prawdy formalnej i realnej. Zakładana przez Leibniza ciągłość substancji jest bowiem niczym innym, aniżeli wynikiem logicznego postulatu wskazującego na niemożliwość nieskończonego regresu dzielenia. Głosi on, że nawet przy najdalej idącym rozkładzie pozostać musi pewien agregat właściwości, stanowiący podstawę dalszego podziału, czyli coś co jest niezniszczalne i zawsze identyczne. Nieśmiertelność duszy nasuwa się tym samym jako efekt aksjomatu tożsamości pojęcia substancji, czyli wywiedziona zostaje $\mathrm{w}$ ramach zasady niesprzeczności logicznej. Dowodowi przez niesprzeczność przeczy jednak w oczywisty sposób drugie kryterium epistemologii Kanta, tzn. obserwacja przypadłości realnych. Ta skłania raczej do twierdzenia, że substancje - nie jako wartości logiczne, a empiryczne podlegają zmianom, także zmianom definitywnym dostrzeganym jako fakt powstawania i ginięcia.

Stając wobec konieczności dowodu na nieśmiertelność duszy Kant nie mógł zatem posłużyć się wybiegiem zastosowanym wcześniej w przypadku dowodu ontologicznego, gdyż - wyjąwszy deklarację biblijnego objawienia brak tu jakiejkolwiek możliwości weryfikacji prawdy poznania. Nie widział 
także żadnych perspektyw, by wobec kresu każdego doświadczenia, jakim jest śmierć, weryfikację taką kiedykolwiek uzyskać. Dlatego też ostro występuje przeciw tezie, że możliwość komunikowania prawd eschatologicznych stwarzają na przykład ogłoszone podówczas drukiem doznania szwedzkiego mistyka i jasnowidza Emanuela Swedenborga. Niejasno sformułowane relacje o nadzmysłowej percepcji „stanu dusz po śmierci” uznawał za posiadające wartość co najwyżej literacką, nigdy filozoficzną ${ }^{17}$.

Reasumując powyższe spostrzeżenia, warto zwrócić uwagę na fakt, że niewiarygodność dowodu na nieśmiertelność duszy była jedną z decydujących przyczyn wzbudzających podejrzenia co do wiarygodności metafizyki w ogóle. Nawet dokonanie niezbędnych z punktu widzenia Kanta korekt epistemologicznych nie pozwalało na ugruntowanie systemu wiedzy na proponowanych przez Leibniza matematyczno-logicznych kryteriach prawdziwości. Według stanowiska królewieckiego filozofa kryteria te nie są, jak wiemy, wystarczająco obiektywne, a z kolei próba ich modyfikacji, czyli dążenie do zgodności wiedzy logicznej i empirycznej nie da się przeprowadzić w sposób systematyczny. Pociąga ona za sobą konieczność przyjmowania kolejnych wyjątków, które mimo wszystko nie prowadzą do całkowitego wykończenia systemu poznania, jako że nie istnieje związek między głównymi kategoriami metafizyki, tj. pojęciem Boga i pojęciem wolności. Związek ten udałoby się uzyskać tylko poprzez stwierdzenie, że podmiotowa wolność stanowi warunek ostatecznego celu człowieczeństwa realizowanego w pojęciu Boga, a to wymaga brakującego dowodu na nieśmiertelność.

Dlatego w kolejnych pismach Kanta na plan pierwszy wysuwa się problem definicji funkcjonowania zasad matematyczno-logicznych w metafizyce, a więc pośrednio również definicji samej metafizyki. W tym aspekcie podstawowym zadaniem filozofii staje się problem metody, która stwarzałaby możliwości uzasadnienia wiedzy wedle warunków poznania w całości obiektywnego, tzn. pewnego bez konieczności dopuszczania „szczególnych wyjątków” i zgodnego jednocześnie z obydwoma postulatami prawdy.

Dokonując prezentacji pierwszych wypracowanych przez Kanta w tym celu pomysłów epistemologicznych, odwołajmy się do znanych już zasad leibnizowskiej teorii poznania. Jak pamiętamy, system Leibniza wyprowadzony został z pryncypiów matematyki, według których rachunek algebraiczny „X $=\mathrm{x}$ " stanowił fundament zasady niesprzeczności oraz, przynajmniej w za-

${ }^{17}$ Krytyce pism Swedenborga poświęca Kant rozprawę Marzenia jasnowidzącego objaśnione przez marzenia metafizyki (1766). 
łożeniu, zasady racji. Zasada niesprzeczności wyrażająca prawdę aprioryczną, dostarcza dowodu tej prawdy poprzez równanie identyczności podmiotu i orzeczenia. Prawdziwe są zatem tylko te zdania, których orzeczenie tkwi $\mathrm{w}$ podmiocie (praedicatum inest subjecto): „x jest x” jest zdaniem prawdziwym, bo „x" zawarte jest $\mathrm{w}$ „x”, analogicznie jak „x jest nie $\mathrm{x}$ ” jest zdaniem sprzecznym, bo "nie x" w podmiocie się nie zawiera. W konsekwencji zdanie identyczne posiada charakter zdania analitycznego, w którym poznanie nie wyraża się w dołączaniu (syntezie) nowych treści poznawczych, lecz w analizie stosunku pojęć uprzednio danych. Logiczny dowód prawdy sprowadza się tym samym zawsze do zdań analitycznych. Metoda poznania analitycznego jako warunek dowodzenia prawdy w ogóle dotyczy w równym stopniu także zdań aposteriorycznych, ujmowanych przez zasadę racji. Wiemy już, że podstawowym aksjomatem zasady racji jest ten, iż „nie ma wyznaczeń czysto zewnętrznych", racje wykładane są tu także jako tkwiące w podmiotach $\mathrm{i}$ identyczne $\mathrm{z}$ ich pojęciem predykatu.

\begin{abstract}
The Relations between Leibniz Ontology and the Early Views of Kant

The article deals with the relation between the monadist metaphysics of Leibniz with the early views of Kant, especially in the field of ontology. The special stress is put on two treatises of Kant, which are attributed to the so-called pre-critical period: Principiorum primorum cognitionis metaphysicae nova dilucidatio and Der einzig mögliche Beweisgrund zu einer Demonstration des Daseins Gottes. In both of them Kant encounters the problem of ontological argument for the existence of God, and, in result, the problem of reason for ontological argument as such. Although in these writings the philosopher does not take so critical stand as in The Critique of Pure Reason, but he also distances himself from Leibniz's standpoint.
\end{abstract}

